when re-introduced following a short withdrawal. Unlike the other patients who remitted on oxymetholone, these two patients had responded despite a markedly hypoplastic marrow. It would seem that if the patients with severe aplasia respond they may become wholly oxymetholone dependent and should be kept on the drug till there is a definite evidence of repopulation of the bone marrow. The withdrawal of therapy in such cases should be very slow and cautious.

In conclusion oxymetholone appears to be of definite value in patients with some erythropoietic areas in the marrow but the prognosis in patients with marked hypoplasia remains very grave.

\section{References}

Alexanian, R., Nadell, J. \& Alfrey, C. (1972) Oxymetholone treatment for the anaemia of bone marrow failure. Blood, 40, 353.

Allen, D.M., Fine, M.R., Necheles, T.F. \& DamasheK, W. (1968) Oxymetholone therapy in aplastic anaemia. Blood, $32,83$.

BOMFORD, R.R. \& RHOADS, C.P. (1941) Refractory anaemia. Quarterly Journal of Medicine, 10, 175.

DACIE, J.V. \& LewIS, S.M. (1968) Practical Haematology, 4th Edn. Churchill, London.

Daiber, A., Herve, L., Con, I. \& Donoso, A. (1970) Treatment of aplastic anaemia with Nandrolone Decanoate. Blood, 36, 748.

Delamore, I.W. \& Geary, C.G. (1971) Aplastic anaemia, acute myeloid leukaemia and oxymetholone. British Medical Journal, 2, 743.

ISRAEL, M.C.G. \& WiLkinson, J.F. (1961) Idiopathic aplastic anaemia. Lancet, i, 63.

JePSON, J.H. \& Lowenstein, L. (1967) The effect of testosterone, adrenal steroids and prolactin on erythropoiesis. Acta Haematologica, 38, 292.
KENNEDY, B.J. \& GiLbertSen, A.S. (1956) Increased erythropoiesis induced by androgenic hormones. Journal of Clinical Investigations, 35, 717.

LEWIS, S.M. (1965) Course and prognosis in aplastic anaemia. British Medical Journal, 1, 1027.

MCCREDIE, K.B. (1969) Oxymethalone in refractory anaemia. British Journal of Haematology, 17, 265.

McCullagh, E.P. \& JoNEs, T.R. (1942) Effect of androgens on blood count of men. Journal of Clinical Endocrinology, 2, 243.

Mohler, D.N. \& Leavell, B.S. (1958) Aplastic anaemia: an analysis of 50 cases. Annals of Internal Medicine, 49, 326.

Pfeiffer, C.A. \& GARpNer, W.V. (1938) Skeletal changes and blood serum calcium levels in pigeons receiving oestrogens. Endocrinology, 23, 485.

REYNAFARJE, C. \& FAURA, J. (1967) Erythrokinetics in the treatment of aplastic anaemia with methandrostenolone. Archives of Internal Medicine, 120, 654.

Sanchez-Medal, L., Gomez-Leal, A., Duarte, L. \& Rico, M.G. (1969) Anabolic androgenic steroids in the treatment of acquired aplastic anaemia. Blood, 34, 283.

Sanchez-Medal, L., Pizzuto, J., Torre-Lopez, E. \& DERBEZ, R. (1964) Effect of oxymetholone in refractory anaemia. Archives of Internal Medicine, 113, 721.

Scott, J.L., Cartwright, G.E. \& Wintrobe, M.N. (1959) Acquired aplastic anaemia: an analysis of 39 cases and review of the pertinent literature. Medicine (Baltimore), 38, 119.

Shahidi, N.T. \& Diamond, L.K. (1961) Testosteroneinduced remission in aplastic anaemia of both acquired and congenital types. New England Journal of Medicine, 264, 953 .

Silink, S.J. \& Firkin, B.G. (1968) An analysis of hypoplastic anaemia with special reference to the use of oxymetholone ('Adroyd') in its therapy. Australian Annals of Medicine, 17, 224.

Vincent, P.C. \& De Gruchy, G.C. (1967) Complications and treatment of acquired aplastic anaemia. British Journal of Haematology, 13, 977.

Wintrobe, M.M. (1967) Clinical Haematology. 6th Edn. Kimpton, London.

\title{
The use of dicobalt edetate (Kelocyanor) in cyanide poisoning
}

\author{
B. HillmaN \\ M.B., Ch.B.(Bristol), M.R.C.P.(UK)
}

K. D. BARDHAN

D.Phil.(Oxon), M.B.B.S.(Madras), M.R.C.P.(UK)

\author{
J. T. B. BAIN \\ M.B.B.S.(Glasgow), D.R.C.O.G. \\ The Department of Medicine, The Royal Hospital, West Street, Sheffield, S1 3SR and \\ Imperial Chemical Industries Ltd, Billingham, Teesside, TS23 1LE
}

\section{Summary}

A case of accidental poisoning with sodium cyanide is reported. The patient was treated with a new antidote, dicobalt edetate (Kelocyanor). Blood levels of cyanide were shown to fall markedly.

\section{Introduction}

The standard treatment of cyanide poisoning has been the rapid intravenous administration of sodium nitrite followed by sodium thiosulphate (Chen, Rose and Clowse, 1934; Chen and Rose, 1952, 1956). 
Recently, it has been suggested that dicobalt edetate (Kelocyanor) is as effective and less toxic an antidote (Bain and Knowles, 1967; Thomas and Brooks, 1970). It has already been shown to be effective in cases of poisoning by inhalation (Bain, 1967, unpublished observations), but we are unable to find any published reports of its use in the more difficult situation of poisoning by ingestion. This case report describes the use of dicobalt edetate in a case of accidental poisoning by sodium cyanide. This case is also unusual in that serial blood levels of cyanide, measured over a prolonged period, were made available; the levels fell with treatment.

\section{Case report}

A 68-year-old man accidentally drank a quantity of sodium cyanide. Two to 3 min later he collapsed. His general practitioner found him, $15 \mathrm{~min}$ later (6.45 p.m.), cyanosed and in respiratory distress. On arrival at the hospital, $55 \mathrm{~min}$ after ingesting the poison (7.25 p.m.), he was apnoeic and pulseless, but bright pink. These appearances were consistent with cyanide poisoning.

The electrocardiogram (ECG), on arrival, showed a slow idioventricular rhythm. Resuscitation was commenced, which included $125 \mathrm{mEq}$ intravenous sodium bicarbonate. There was no change in his condition or on the ECG. The first dose of Kelocyanor was now given intravenously (the contents of one $20 \mathrm{ml}$ ampoule containing $300 \mathrm{mg}$ of dicobalt edetate). The pulse became palpable almost immediately; he developed sinus tachycardia, the systolic blood pressure rose to $60 \mathrm{~mm} \mathrm{Hg}$, but no spontaneous respirations occurred. Therefore further single doses of Kelocyanor were given, 10 and 15 min after the initial dose. There was, however, no change in his condition. The stomach was now washed out with a mixture of ferrous sulphate, citric acid and sodium bicarbonate, and a quantity was left in situ (Blacow, 1967). Mechanical ventilation was started at 8.30 p.m. At 9.00 p.m., spontaneous respirations occurred and by 9.30 p.m., the patient was hyperventilating with a tidal volume of 1.81 , and a minute volume of 251 . At this time an arterial blood sample showed the following: $\mathrm{pH} 7 \cdot 465, \mathrm{pCo}_{2}$ $17 \mathrm{~mm}, \mathrm{pO}_{2} 95 \mathrm{~mm}$, calculated bicarbonate 11.8 $\mathrm{mEq}$. The pulse now became irregular with ectopic atrial activity, and the systolic blood pressure, which had risen to $90 \mathrm{~mm} \mathrm{Hg}$, fell to $60 \mathrm{~mm} \mathrm{Hg}$. The fourth dose of Kelocyanor was given, which was immediately followed by a further, but transient, fall in blood pressure and tachycardia. At 4.30 a.m. respirations ceased and did not return even after a further dose of Kelocyanor. Mechanical ventilation was therefore recommenced. Two hours later the sixth dose of Kelocyanor, within the first $12 \mathrm{hr}$ period, was given. Shortly after, the patient passed melaena stools. The blood pressure fell and he was transfused 11 of blood. He remained unconscious $C$ throughout; it was assumed that further absorption of cyanide was occurring. Nine further doses of $\stackrel{\vec{\sim}}{\stackrel{\vec{T}}{+}}$ Kelocyanor were given at half-hourly intervals? throughout the afternoon to counteract this, but $\frac{\bar{\sigma}}{\bar{N}}$ without any change in his condition. He appeared to $\frac{\bar{\rho}}{\frac{\sigma}{\alpha}}$ have irreversible brain damage. He developed $\stackrel{\mathbb{\Phi}}{\propto}$ asystolic cardiac arrest $44 \mathrm{hr}$ after admission.

\section{Investigations}

Venous blood was taken throughout treatment for estimation of cyanide levels although the results $\stackrel{\sigma}{\sigma}$ would not be available for some days (Table 1). 8 The blood was stored in plastic vials containing $1 \% 3$. sodium fluoride. Sodium fluoride prevents the production of cyanide in stored blood; this source of ir error was therefore eliminated (Curry, Price and $\stackrel{\infty}{-}$ Rutter, 1967; Simpson, 1971, personal communica- $\overrightarrow{\vec{v}}$ tion). The cyanide levels were measured by the $\beth$ method of Gettler and Goldbaum (1947).

\begin{tabular}{|c|c|c|}
\hline Time & $\begin{array}{c}\text { Blood } \\
\text { Cyanide } \\
\text { levels } \\
\mu \mathrm{g} / 100 \mathrm{ml}\end{array}$ & Comments \\
\hline $\begin{array}{l}\text { Day } 1 \\
7.30 \text { p.m. }\end{array}$ & $550 \mu \mathrm{g}$ & On admission \\
\hline $\begin{array}{l}\text { Day } 2 \\
9.00 \text { a.m. }\end{array}$ & $30 \mu \mathrm{g}$ & $\begin{array}{l}1800 \text { diCo.ed. given in previous } \\
12 \mathrm{hr}\end{array}$ \\
\hline 4.00 p.m. & $100 \mu \mathrm{g}$ & $\begin{array}{l}\text { Further } 1200 \mathrm{mg} \text { diCo.ed. given in } \\
\text { previous } 2 \mathrm{hr}\end{array}$ \\
\hline $\begin{array}{l}\text { Day } 3 \\
9.00 \text { a.m. }\end{array}$ & $20 \mu \mathrm{g}$ & $\begin{array}{l}\text { Further } 1500 \mathrm{mg} \text { diCo.ed. given } \\
\text { after } 4 \text { p.m. on day } 2 \text {. Died } 3.30 \\
\text { p.m. }\end{array}$ \\
\hline Day 4 & $8 \mu \mathrm{g}$ & $\begin{array}{l}\text { Axillary vein blood obtained at } \\
\text { post mortem }\end{array}$ \\
\hline
\end{tabular}

diCo.ed. = dicobalt edetate (Kelocyanor).

At autopsy, more blood, brain, bile and urine were collected for cyanide estimations (Table 2). The initial blood level of cyanide exceeded the 9 suggested lethal level of $250 \mu \mathrm{g} / 100 \mathrm{ml}$ (Bain, 1971, unpublished observation). There was a marked fall followed by a rise in spite of treatment, and then a $N$ further fall as treatment was continued. Blood levels of various enzymes rose (Table 3). The cause of the low serum level is not clear, but it may be related to the antidote.

TABLe 2. Cyanide levels at post mortem

\begin{tabular}{ll}
\hline & Cyanide levels \\
\hline Bile & $300\} \mu \mathrm{g} / 100 \mathrm{ml}$ \\
Urine & $100\}\}^{2}$ Noin detected \\
\hline
\end{tabular}


TABLE 3. Blood biochemistry

\begin{tabular}{lccc}
\hline \multicolumn{1}{c}{ Enzymes, miu/ml* } & \multicolumn{3}{c}{ Hours after admission } \\
\cline { 2 - 3 } & 18 & 39 & $\begin{array}{c}\text { Normal } \\
\text { range }\end{array}$ \\
\hline $\begin{array}{l}\text { Aspartate } \\
\text { aminotransferase }\end{array}$ & 81 & 900 & $0-40$ \\
$\begin{array}{l}\text { Alanine } \\
\text { aminotransferase }\end{array}$ & 59 & 480 & $0-30$ \\
$\begin{array}{l}\text { Creatine } \\
\text { phosphokinase }\end{array}$ & 155 & 1200 & $0-70$ \\
$\begin{array}{l}\text { Hydroxybutyrate } \\
\text { dehydrogenase }\end{array}$ & 105 & 740 & $0-200$ \\
\hline
\end{tabular}

Serum bilirubin and alkaline phosphatase normal. Prothrombin time $2 \frac{1}{2}$ times greater than control. Serum calcium $5.0 \mathrm{mg} / 100 \mathrm{ml}$. ${ }^{*} \mathrm{miu} / \mathrm{ml}=$ milli International Units $/ \mathrm{ml}$.

At autopsy the brain was oedematous and hyperaemic with evidence of marked coning. The ventral surface of the pons and medulla was necrotic. The heart was dilated; several subepicardial ecchymoses were noted on the posterior surface. The gastrointestinal tract showed extensive acute haemorrhagic gastritis, oedema of the small and large bowel throughout its length, two necrotic areas in the ileum and a small liver infarct. The renal cortex was infarcted in several places. The lungs were oedematous in areas and the upper lobe were collapsed.

\section{Discussion}

Cyanide is widely used in modern industry. However, industrial poisoning is rare owing to stringent precautions, and when it does occur, it is generally by inhalation. Outside industry, poisoning is usually by ingestion but this is now a rare event. Consequently, experience in the management of this form of poisoning is very limited.

Cyanide owes its lethal properties to its strong affinity for the ferric ions in the cytochrome oxidase system thus blocking it and leading to cytotoxic hypoxia (Keilen and Hartree, 1939). The main aim of treatment is to remove the cyanide from the ferric ions (Chen et al., 1934; Chen and Rose, 1952, 1956; Done, 1961; Lovatt Evans, 1964; Goodman and Gilman, 1970). This has traditionally been achieved by the rapid intravenous administration of sodium nitrite followed by sodium thiosulphate. In a case such as ours, where poisoning is severe and large amounts of antidote would be required, the amount of methaemoglobin formed would be so great as to preclude the use of nitrite. In addition, the hypotensive effects of sodium nitrite, which is often severe and prolonged, is dangerous, not only in the patient poisoned with cyanide but also in cases of cerebrovascular accidents and myocardial infarction, the differential diagnosis of which enters into that of cyanide poisoning, particularly in industry (Bain and Knowles, 1967). In other words, large doses of sodium nitrite will result in severe anoxia and hypotension and can, by itself, be fatal (Lovatt Evans, 1964; Kiese and Weger, 1969).

Cobalt compounds have long been known to be effective antidotes to cyanide but were themselves toxic. Chelation of cobalt removes the toxic effects; dicobalt edetate appears to be the most satisfactory of these compounds (Mushett et al., 1952; Paulet, 1960; Lovatt Evans, 1964). This compound is believed to react with cyanide to form cobalticyanide, $\mathrm{CO}(\mathrm{CN})_{6}{ }^{3-}$, and monocobalt edetate, both of which are excreted in the urine within $24 \mathrm{hr}$ of administration (Bain, unpublished observations, 1971). Kelocyanor, the commercially available form of dicobalt edetate, is supplied in $20 \mathrm{ml}$ ampoules, each containing $300 \mathrm{mg}$ of the compound in $20 \%$ glucose. The manufacturers recommend that $20 \mathrm{ml}$ is injected intravenously and if recovery does not ensue, a further two doses should be given. Transient tachycardia and a drop in blood pressure are to be expected.

Dicobalt edetate is generally effective treatment in accidental poisoning by inhalation where the victim would have been removed from the contaminating atmosphere, thus preventing further poisoning (Bain, unpublished observation, 1971). However, in the case of ingested poison, the problem of continued absorption from the intestine arises; the rising blood levels of cyanide following the initial fall in our case suggests that this was, in fact, occurring. The high levels of cyanide in the bile raises the possibility that enterohepatic circulation of cyanide might also occur and contribute to maintaining the rising blood levels. To counteract this, further intravenous dicobalt edetate would be required, either by frequent injections or by continuous infusion. The former method was tried in our patient, with considerable lowering of blood cyanide levels. It has been suggested that administration of ferrous carbonate (formed by mixing solutions of ferrous sulphate, citric acid and sodium carbonate) by nasogastric tube, would retard intestinal absorption of cyanide; this traditional treatment is now considered ineffective. It might be more worthwhile to administer dicobalt edetate instead by this means. As far as is known, this compound, even in large doses, is relatively non-toxic.

The hyperventilation observed in our patient after three doses of Kelocyanor had been administered, is characteristic of low levels of blood cyanide (Goodman and Gilman, 1970), and in our patient, did correspond to falling blood levels. This sign is of potential clinical importance as it indicates effective treatment, particularly as blood cyanide levels generally cannot be measured rapidly enough to guide treatment. 
The appearance of the patient and of the ECG is now well recognized in cyanide poisoning (Wexler, Whittenberger and Dumke, 1947; Chen and Rose, 1952, 1956; Lee-Jones, Bennett and Sherwell, 1970).

The features at autopsy may represent a combination of cytotoxic hypoxia and hypotension and possibly the effects of the antidote; in animals, cobalt salts cause oedema of the small intestinal mucosa (Lovatt Evans, 1964).

In conclusion, dicobalt edetate appears to be effective in lowering blood cyanide levels. Our patient probably suffered from irreversible anoxic brain damage in the nearly hour long delay before treatment could be started. Had this delay not occurred and possibly more antidote given, the patient may well have survived. In further cases, more frequent administration of dicobalt edetate, possibly by continuous intravenous infusion, and also by direct administration into the stomach, if started sufficiently early, may prove to be the treatment of choice in severe poisoning by ingestion as the amount of sodium nitrite-thiosulphate required to produce a similar reduction of blood cyanide levels would in itself be lethal.

\section{Addendum}

Another patient was admitted after having taken a small quantity of sodium cyanide. He collapsed a few minutes later but did not lose consciousness.

Two ampoules of di-cobalt edetate were given intravenously and (one $4 \mathrm{hr}$ later) he then developed sweating, angina, ventricular ectopic beats and intense nausea and vomiting. The antidote was discontinued whereupon his symptoms cleared. It is presumed that the latter were due to di-cobalt edetate.

Thirty-six hours later he was quite well but then developed a red maculo-papular rash over his chest and arms which started to fade the following day. It is presumed that the rash was a side effect of the antidote; this has not been described before.

Di-cobalt edetate (Kelocyanor) is manufactured by Laboratories Laroche Navarron, 63 Rue Chappal, Levallois, Paris, and is imported into the United Kingdom by Boots (Nottingham).

\section{Acknowledgments}

We wish to express our thanks to Professor Sir Charles $\mathbf{H}$. Stuart-Harris for permission to report this case and the medical and nursing staff of the Intensive Therapy Unit for their help. Dr A. Usher, Home Office Pathologist, performed $C$ the autopsy and kindly arranged for the cyanide estimations; the assay was carried out by Mr G. S. Simpson, Principal Scientific Officer of the East Midland Forensic Science Laboratories, Shakespeare Street, Nottingham. Our thanks to both.

Our gratitude to Dr P. Howard, Senior Lecturer, for reading the script.

\section{References}

BAIN, J.T.B. \& KNOWLES, E.L. (1967) Successful treatment of cyanide poisoning. British Medical Journal, 2, 763.

Blacow, N.W. (1967) Martindale's Extra Pharmacopoeia, 25th Edn. Pharmaceutical Press, for the Pharmaceutical Society, London.

CHEN, K.K. \& Rose, C.L. (1952) Nitrite and thiosulphate therapy on cyanide poisoning. Journal of the American Medical Association, 149, 113.

CHEN, K.K. \& Rose, C.L. (1956) Treatment of acute cyanide poisoning. Journal of the American Medical Association, $162,1154$.

Chen, K.K., Rose, C.L. \& Clowes, G.H.A. (1934) Comparative values of several antidotes in cyanide poisoning. American Journal of Medical Sciences, 188, 767.

Curry, A.S., Price, D.E. \& RutTer, E.R. (1967) The production of cyanide in post-mortem material. Acta Pharmacologica et Toxicologica, 25, 339.

DoNE, A.K. (1961) Clinical pharmacology of systemic antidotes. Clinical Pharmacology and Therapeutics, 2, 750.

Goodman, L.S. \& Gilman, A. (1970) The Pharmacologicat Basis of Therapeutics. 4th Edn. The Macmillan Company London and Toronto.

Gettler, A.O. \& Goldbaum, L. (1947) Detection an estimation of microquantities of cyanide. Analytical Chemistry, 19, 270.

Keilen, D. \& Hartree, E.F. (1939) Cytochrome and cytochrome oxidase. Proceedings of the Royal Society. B Series, $127,167$.

KIESE, M. \& Weger, N. (1969) Formation of ferrihaemoglobin with aminophenols in the human for the treatment of cyanide poisoning. European Journal of Pharmacology, $7,97$.

Lovatt Evans, C. (1964) Cobalt compounds as antidotes for hydrocyanic acid. British Journal of Pharmacology, 23, 455.

Lee-Jones, M., Bennett, M.A. \& Sherwell, J.M. (1970) Cyanide self poisoning. British Medical Journal, 4, 780.

Mushett, C.W., Kelley, K.L., BoXer, G.E. \& Rickards, J.C. (1952) Antidotal efficacy of vitamin $B_{12}$ a (hydroxocobalamin) in experimental cyanide poisoning. Proceedings of the Society for Experimental Biology and Medicine, 81, 234.

PAULET, G. (1960) L'Intoxication cyanhydrique et son traitement, 1st Edn. Masson, A.C., Paris.

Thomas, T.A. \& Brooks, J.W. (1970) Accidental cyanide poisoning. Anaesthesia, 25, 110.

WeXler, J., Whittenberger, J.L. \& Dumke, P.R. (1947) The effect of cyanide on the electrocardiogram. American Heart Journal, 34, 163. 